\title{
Vozes da Loucura Cantada: Sentidos sobre a Loucura e o Louco em Canções Brasileiras.
}

\author{
Voices of Madness in Song: \\ Outlooks on Madness and the Insane in Brazilian Songs
}

João Paulo Pereira Barros ${ }^{1}$

Maria Salete Bessa Jorge ${ }^{2}$

${ }^{1}$ Departamento de psicologia, Universidade Federal do Ceará. Avenida da Universidade 2853, Benfica. 60020-181

Fortaleza CE.

jppbarros@yahoo.com.br

${ }^{2}$ Departamento de Saúde

Pública, Universidade

Estadual do Ceará
Abstract This article is the result of research associated with the representation of madness and the insane in contemporary Brazilian songs. Michel Foucault's considerations about the history of madness and those of Mary Jane Spink about discursive practices and the production of meaning formed the theoretical base for the study. The methodology consisted in mapping the circulation of words and meanings about madness in thirty songs collected by Google's search engine. The results of the mapping reveal the polyphony of the literary/musical discourse, and a heterogeneous discursive panorama in which five zones of meaning about madness and the insane stand out. Thus, it can be concluded that these signs are prevalent on a day-to-day basis, Some of the meanings in the songs refer to institutionalized ways of dealing with madness, others constitute modes of subjectivity that flee from routine treatment. By delineating symbolic formations that permeate social imagery, this article brings systematic attention to popular representations of various forms of madness of relevance to multidisciplinary fields in mental health, discussing their appearance in popular music and their possible repercussions.

Key words Discursive practices, Production of meaning, Mad, Madness, Mapping
Resumo $O$ artigo resulta de uma pesquisa que objetivou compreender os sentidos sobre a loucura e o louco que atravessam canções brasileiras contemporâneas. As considerações de Michael Foucault sobre a História da Loucura e as de Mary Jane Spink sobre práticas discursivas e a produção de sentidos formaram as bases teóricas do estudo. A metodologia consistiu na realização de uma cartografia da circulação de sentidos sobre o louco e a loucura em trinta canções reunidas pelo motor de busca Google. Os resultados da cartografia indicam a polifonia do discurso literomusical e apontam uma paisagem discursiva heterogênea onde se destacam cinco zonas de sentido sobre a loucura e o louco. Conclui-se que estes signos estão em disputa no dia-a-dia, sendo que alguns sentidos circulantes nas canções remetem a modos instituídos de lidar com essa situação, enquanto outros podem constituir vetores de subjetivações fugidias às normalizações cotidianas. Assim, ao realçar algumas conformações simbólicas que perpassam o imaginário social, o artigo chama a atenção para a relevância de o campo multidisciplinar da saúde mental escutar as vozes sociais sobre as várias loucuras, perscrutando suas condições de produção e suas possiveis ressonâncias.

Palavras-chave Práticas discursivas, Produção de sentidos, Louco, Loucura, Cartografia 


\section{Introdução}

A reforma psiquiátrica há anos em processo no Brasil tem propiciado transformações nas reflexões sobre a temática da saúde mental, além da implantação de novos modelos de assistência e novas estratégias de cuidado. Nesse contexto, a desinstitucionalização da loucura se tornou um dos seus pilares e um dos fundamentos da política de saúde mental, sendo compreendida como "desconstrução de saberes, discursos e práticas psiquiátricos que sustentam a loucura reduzida ao signo da doença mental e reforçam a instituição hospitalar como a principal referência da atenção à saúde mental”"

Assim, a desinstitucionalização não se resume a substituir o manicômio por outros serviços que viabilizem a "reinserção" das pessoas com transtornos mentais nos cotidianos da cidade, visto que a configuração da política e dos serviços não garante, por si só, o arrefecimento de relações excludentes observadas na lógica manicomial, por exemplo. Mais que isso, a proposta de desinstitucionalização demanda a constituição de relações pautadas em novas bases epistemológicas e políticas, de modo que mudanças sejam operadas nas práticas que alicerçam a discriminação e as diversas modalidades de aprisionamento da loucura, inclusive "a céu aberto".

Destarte, Alverga e Dimenstein ${ }^{2}$ frisam a relevância para o campo da saúde mental de que a própria dinâmica da sociedade seja problematizada. Logo, um ponto fulcral para tal é a reflexão sobre os discursos relativos aos processos saúdedoença mental circulantes no dia-a-dia. Em específico, faz-se pertinente à efetivação da reforma psiquiátrica perscrutar sentidos sobre o louco e a loucura que permeiam produções de nossa cultura, visto que isso ainda constitui uma lacuna de pesquisas desenvolvidas no campo da saúde mental, considerando os vultosos desafios atuais relacionados à desinstitucionalização da loucura.

De tal modo, a pesquisa aqui relatada teve o objetivo de compreender os sentidos sobre a loucura e o louco que atravessam canções brasileiras contemporâneas. Pretendemos especificamente: (a) identificar sentidos sobre louco e loucura circulantes em canções brasileiras contemporâneas; (b) compreender as condições históricas de produção dos sentidos sobre o louco e a loucura veiculados pelas canções analisadas e (c) discutir possíveis implicações dos discursos literomusicais sobre o louco e a loucura para o campo da saúde mental.

Para tanto, os apontamentos de Michael Foucault $^{3}$ sobre a História da Loucura nos serviram de subsidio teórico. Também fizeram parte de nosso referencial os apontamentos de Mary Jane Spink ${ }^{4}$ sobre práticas discursivas e produção de sentidos, os quais congregam reflexões de Foucault acerca do discurso e construtos de Bakhtin ${ }^{5}$ sobre os processos de enunciação.

De acordo com a investigação arqueológica foucaultiana, a loucura é abordada como produção histórico-social. A partir daquela investigação, podemos acompanhar transformações importantes na percepção da loucura em diferentes momentos da história ocidental. Dentre tais transformações, merece destaque a fenda existente entre uma "experiência trágica" e uma "consciência crítica" do enlouquecimento, a partir do século XVI; a figuração da loucura no universo da Desrazão, na Idade Clássica; a ligação entre loucura e alienação, no final do século XVIII; e a produção da doença mental como objeto e da psiquiatria no século XIX ${ }^{3}$.

Sobre a oposição entre a "experiência trágica" e a "experiência crítica" da loucura, vale fazer referência ao estudo de Cunha ${ }^{6}$, que aponta que os "diferentes" existiram em todas as sociedades, mas que foram encarados diferentemente, em consonância com os diferentes sistemas políticos. Seu estudo mostra, por exemplo, transformações na forma de encarar o "louco" entre o século XIX e o início do regime republicado brasileiro: de figura engraçada, que vivia pelas ruas das cidades, o "louco" passou a figurar como doente com periculosidade considerada, devendo, por isso, ocupar os hospícios e ser tratado por profissionais especializados.

Â luz dessa perspectiva, abordar as atuais relações de nossa sociedade com a loucura requer, pois, estudar as práticas discursivas que atravessam o cotidiano. Para Foucault, o conceito de prática discursiva implica que a linguagem é uma ação que produz efeitos e que o discurso consiste em "um conjunto de regras anônimas, históricas, sempre determinadas no tempo e no espaço, que definiram, em uma dada época e para uma determinada área social, econômica, geográfica ou linguística, as condições de exercício da função enunciativa"'.

Já para Spink e Frezza ${ }^{8}$, as práticas discursivas são os modos a partir dos quais as pessoas compõem sentidos e se posicionam em relações sociais no cotidiano. Por seu turno, sob esse prisma, os sentidos são acontecimentos resultantes de negociações nas práticas discursivas, sendo que sua produção se dá pelo confronto de vozes sociais que precedem e perpassam a construção de todo e qualquer enunciado.

Então, as canções podem ser vistas como práticas discursivas relativas a um tipo de discurso 
chamado de literomusical, conforme pesquisas já realizadas sobre o tema ${ }^{9,10}$. Compreendemos, ainda, que as canções são "nós de uma intricada configuração interdiscursiva" que indicam modos de sentir e interpretar situações do contexto sociocultural, além de darem sentidos aos atos da coletividade e também imprimirem movimento a esse contexto.

Diante dos resultados da pesquisa, esperamos que este artigo traga contribuições à leitura das práticas discursivas que evocam os signos do louco e da loucura no cotidiano. Ademais, esperamos acrescentar novos elementos para a discussão sobre as sociabilidades contemporâneas, para a compreensão de como nossa sociedade se relaciona com a experiência da loucura e desejamos contribuir para a invenção de práticas no campo da saúde mental.

Não obstante, acreditamos que a relevância do estudo transborda o campo multidisciplinar da saúde mental stricto sensu. Pesquisas como a que aqui é relatada, cujo objeto se enlaça ao campo da cultura, podem ampliar a compreensão sobre sentidos que transitam na esfera pública e que habitam o imaginário social sobre a saúde e sobre a doença, endossando os esforços empreendidos pelo campo à Saúde Coletiva para consolidar o caráter multidimensional do processo saúde/doença, para salientar as relações de tal processo com o contexto sócio-histórico e para afirmar a necessidade de intervenções que compreendam e problematizem as práticas culturais e os saberes sobre saúde e doença que as orientam.

\section{Metodologia}

\section{Tipo de estudo}

A metodologia deste estudo teve natureza qualitativa e consistiu na realização de uma cartografia da circulação de sentidos sobre o louco e a loucura nas canções que formaram o corpus da pesquisa, entendendo que as canções se configuram também como um território semiótico. Segundo Rolnik ${ }^{11}$, o método cartográfico constitui uma conexão de linhas de uma "paisagem psicossocial”, de modo a formular um "desenho" que indique movimentos, oscilações, devires e virtualidades a partir dos traços que marcam os territórios destacados.

A cartografia se operacionalizou pela análise de documentos de domínio público, especificamente canções brasileiras em circulação na contemporaneidade que veiculam sentidos sobre o louco e a loucura. A escolha desse caminho se justifica porque, para Mello et al. ${ }^{12}$, os diversos documentos de domínio público, como canções, notícias jornalísticas e outros textos, são profícuos aos estudos sobre a produção e veiculação de sentidos no cotidiano, podendo refletir transformações nas versões circulantes assumidas nas práticas discursivas e nas redes sociais.

\section{Fontes}

Optamos pelo uso de fontes oriundas da internet, o que nos permitiu acesso a um vasto e atual leque de composições musicais, ao mesmo tempo em que nos oportunizou a construção de um corpus de pesquisa que desse espaço para a emergência de heterogeneidades. Além de pertinente para a viabilização da construção do corpus, esta escolha se coadunou teoricamente com as observações de Foucault ${ }^{13}$, segundo as quais o discurso é um lugar de dispersão.

O corpus da pesquisa foi construído por trinta canções reunidas mediante o Google, um dos motores de busca mais conhecidos e mais usados da internet, que indexa várias páginas eletrônicas na rede virtual. Na definição das canções, a partir da "navegação" pelo motor de busca, optamos pelo uso dos descritores "letra de música louco" e "letra de música loucura", os quais permitiram o acesso a canções que traziam os signos “louco" e/ou "loucura” não só no título, como também no próprio texto.

Como critério para limitação do número de canções do corpus, de modo que fosse exequível a organização e a análise do material, consideramos somente as canções relacionadas nas dez primeiras páginas do motor de busca, no dia 10/ $11 / 2009$, data da procura do material. Essa escolha se respaldou em consonância aos referenciais teórico-metodológicos de nossa pesquisa com uma perspectiva qualitativa, o que nos fez levar em conta mais a ressonância que a representatividade das canções ${ }^{13}$.

Desse modo, as trinta canções analisadas foram as seguintes: "Agora eu tô bem louco", "Já virou loucura", "O homem Louco", "Dias Loucos”, "Louco por ti", "Eu fico louco", "Louco por você", "Sentimento Louco", "Estranha Loucura”, "Faz uma loucura por mim”, "Só louco", “ o louco", "Imprevisível”, "Loucura Maior”, "Sábia Loucura” "Acho que já é loucura”, "Evidências", "Loucura”, "Paixão ou loucura", "Loucura Demais", "Pára com essa loucura", "Doce Loucura", "Isso é loucura", "Esse amor é loucura", "Nós somos loucos", "Maluco Beleza", "Balada do louco", "Loucos por Deus", Loucura de amor" e "Gentil loucura"14. 


\section{A Análise dos Dados}

Considerando que a cartografia se trata de um método que põe em suspeita a definição de passos a priori, a análise do corpus se orientou por pistas dadas por Kastrup ${ }^{15}$, principalmente as seguintes: a análise deve acompanhar processos e não representar objetos; refere-se a um coletivo de forças; visa um território existencial; traça um campo problemático e requer a dissolução do ponto de vista neutro do observador.

Seguindo tais pistas, a análise das canções procurou considerar a produção interativa e dialógica dos sentidos que atravessavam o texto das canções. Logo, ao se debruçar sobre cada uma das trinta canções que constituíram o corpus analisado, a cartográfica, ao invés de "desvelar" significados e "descortinar" "intenções" dos autores das letras, privilegiou a ancoragem sóciohistórica dos textos literomusicais em exame, a identificação de vozes sociais que se neles presentificavam, a explicitação da multiplicidade de sentidos no processo enunciativo, bem como suas possíveis ressonâncias ${ }^{16}$.

Coerente com a perspectiva cartográfica, a análise empreendida buscou acompanhar a circulação de sentidos sobre o louco e a loucura entendida como um traçado problemático - em um campo movente - o campo do discurso literomusical - e não subsumido ao plano da representação.

Também em consonância com a perspectiva cartográfica, a análise das canções exigiu um exercício cognitivo de implicação no processo dialógico de composição de sentidos, e não de descoberta de sentidos pré-existentes. Nesse traçado, portanto, a composição de sentidos foi compreendida em seu caráter aberto, uma vez que os sentidos sobre a loucura e o louco, por exemplo, não estão nem na mente do falante, nem no texto em si, mas sim na interação dos interlocutores entre si e com o mundo.

\section{Resultados}

A cartografia permitiu vislumbrar um território diversificado. Assim, apresentaremos cinco zonas de sentidos sobre o louco e a loucura identificadas nas canções.

\section{A Loucura como constitutivos mergulhos em si mesmo}

Das trinta canções analisadas, sete remetem à figuração da loucura como uma experiência de encontro constitutivo consigo. A canção "Dias Loucos", de Nando Reis, ilustra meandros desta zona de sentido:

$\mathrm{Na}$ loucura dos meus dias/quero ser são, pra tornar-me louco/Onde lugar comum é viajar nas ilusões de cada um/Cair do abismo dos pensamentos que até a lua chegam e voltam/Na certeza que o certo é relevante/num dia seguinte distante/Quero ser exemplo pro meu filho/Quero ser orgulho pro meu pai/Amor pro meu amor/Servir a meu Senhor/Na loucura dos meus dias/vou conseguindo me fazer ver/Que eu preciso de/alguém que me entenda e que eu consiga entender/Olhar pra frente e fazer planos/deixar pra trás o que me magoou/me dê a mão venha comigo sempre me aceite simplesmente como eu sou/Quero ter orgulho do meu filho/E seguir o exemplo do meu pai/Ser amor só pro meu amor/Servir a meu Senhor/Numa mistura de loucura e lucidez/Vou viajando e me perdendo em ilusão/Será que esse momento é insensatez?/Uma overdose em meu coração. (Grifo nosso ).

Nesta canção, o uso dos signos "louco" e "loucura" se dá pela confrontação de dois sentidos distintos. Por um lado, há um sentido negativo para o louco e a loucura, indicando uma crítica ao modo de vida atual. Por outro, há também um sentido positivo relacionado a atitudes que expressariam o salutar mergulho em si e no outro, abrindo frestas que acenam para outros modos de existência supostamente mais potentes.

A confrontação de sentidos que situam a loucura no âmbito de uma "viagem" construtiva com outros sentidos perfilados a modos instituídos de conceber a loucura também atravessa a canção "Balada do Louco", que, no Google, aparece com a versão de Rita Lee:

Dizem que sou louca/Por pensar assim/Se eu sou muito louca/Por eu ser feliz/Mais louco é quem me diz/E não é feliz, não é feliz/Se eles são bonitos/Eu sou a Sharon Stone/Se eles são famosos/ I"m a Rolling Stone/Mais louco é quem me diz e não é feliz, não é feliz/Eu juro que é melhor/Não ser um normal/Se eu posso pensar Que Deus sou eu/Se eles têm três carros/Eu posso voar/Se eles rezam muito, eu sou santa/Eu já estou no céu/ Mais louco é quem me diz e não é feliz, não é feliz/ Eu juro que é melhor/Não ser um normal/Se eu posso pensar/Que Deus sou eu/Sim, sou muito louca/Não vou me curar/Já não sou a única/Que encontrou a paz/Mais louco é quem me diz e não é feliz/Eu sou feliz! (Grifo nosso).

Há, em tal texto, uma dinâmica enunciativa onde coexistem sentidos antagônicos. O primeiro deles se relaciona à visão da loucura como anormalidade delirante, atribuída ao eu- lírico por 
um sujeito oculto. Este sentido, por sua vez, é contraposto pela visão do eu-lírico, para quem o louco é aquele que não é feliz, mesmo conseguindo atender a padrões de normalidade vigentes nas relações sociais. O sujeito do discurso, por meio do sentido que sustenta e do sentido ao qual interpela, aponta, então, um viés de positividade no delírio.

Nessa canção, é também possível entrever uma sátira às normas e às expectativas contemporâneas. $\mathrm{O}$ dialogismo constitutivo da produção dos enunciados e a polifonia da linguagem aparecem de modo quase "escancarado" no texto literomusical destacado, já que fica factível a relação entre a palavra autoral e a palavra alheia. Neste caso, a polifonia parece se expressar pela atitude do falante em dialogar - numa atmosfera de contraposição - com outras vozes que o considerariam "louco", sendo que o sujeito do discurso faz, neste caso, uso ativo da palavra alheia, ao esboçar respostas a outros discursos passados ou antecipados.

Historicamente, as principais condições de produção e circulação de sentidos da loucura como "encontro consigo" podem ser remontadas pela construção de um discurso relativo à "experiência trágica" da loucura, que alia o desregramento a experiências de expressão e criação. A loucura, neste viés, é, de acordo com a arqueologia foucaultiana, um sutil relacionamento do homem consigo mesmo, configurando-se como um saber sobre vicissitudes humanas. É a respeito da "experiência trágica" que a aquele autor afirma que "a loucura não diz tanto respeito à verdade e ao mundo quanto ao homem e à verdade de si mesmo que ele acredita distinguir"3.

\section{A Loucura na Paixão como Experiência Positiva de Perder-se}

Sete das trinta músicas analisadas foram reunidas nesta zona de sentido. Marcam essas canções a evocação dos signos em debate para evidenciar o "perder-se" de si, e não o mergulho em si mesmo.

A canção "Eu fico Louco", de Wilson Sideral, veicula sentidos a partir dos quais o termo "louco" adjetiva quem se desencontra ao se deixar atravessar pelos fluxos intensivos passionais. Curioso é atinarmos que, neste caso, as ações e sensações associadas ao "ficar louco" são vantajosas ao ser humano.

Ah! eu fico louco/vamos dançar, é, a noite inteira sem parar/vamos ficar, juntos/explodindo de prazer/vamos cantar, é, vamos pular,mexer, suar/ vamos amar, muito, até/querer gritar/vem pra cá, eu tô legal/do jeitinho que você me quer/chega mais perto, vem/me agarra forte, então/vamos fugir desse lugar/ah! eu fico louco assim, é /quando você chega perto/vamos dançar, é,/chacoalhando na sonzeira/vamos ficar, loucos, nesta/sexta-feira/vamos rodar, juntos, pela madrugada/vamos quebrar, tudo, e/acabar na nossa cama/vem pra cá, eu to legal/do jeitinho que você me quer/chega mais perto; vem me agarra forte, então/vamos fugir desse lugar [...] (Grifo nosso).

Em "Louco por Você", cantada por Bruno e Marroni, a loucura e o louco também coincidem com a entrega radical a outrem.

Estou aqui a lhe esperar/Os minutos e segundos a contar/Louco de saudade/Com vontade de te abraçar/Estou contando as horas/Ansioso e com vontade de te amar/Louco de vontade/De sentir o seu cheiro/Sou Louco por você/Faço qualquer coisa para te ver/Não consigo mais pensar/Somente em você, paixão da minha vida/Loucuras nesta vida faço/Nunca fiz coisas malucas assim/Somente por você, só por você/Perco a razão, me foge o raciocínio/Só penso em você/Louco a esperar, com vontade de te ver, Louco para te amar. (Grifo nosso).

Contudo, existe uma particularidade nesta canção. Embora a perda do controle sobre si seja positivada, em algumas passagens a loucura figura como perda da razão e impossibilidade do pensamento, sinais que receberam significação negativa, sobretudo, a partir da Idade Clássica, em função das concepções de sujeito nascentes à época. Então, neste caso, devido ao caráter lúdico do seu discurso, marcado pelo teor conotativo e pela possibilidade de por em jogo vozes bastante diferentes, há uma convivência de sentidos - loucura como entrega fecunda à paixão e como impossibilidade do pensamento - que pareceria inconciliável à luz de outros domínios de saber, como, por exemplo, a Filosofia Cartesiana e o saber psiquiátrico.

\section{A Loucura \\ como acesso místico à verdade}

As duas canções relativas a esta zona - "Loucos por Deus" e "Sábia Loucura”, nas versões dos cantores Vanilda Bordieri e PG, respectivamente, segundo aparece no motor de busca - remetem a uma temática religiosa. Em "Loucos por Deus", há um discurso caracterizado pelo fechamento da polifonia, em função da tentativa de prescrever um sentido unívoco aos interlocutores:

São desprezados e até humilhados/Mal entendidos, incompreendidos/Lixo, refugo, inimigos do mundo/Ao céu tem acesso, amigos de Deus/Classi- 
ficados como simples loucos/Infelizmente não passam de poucos/Mas isso não é problema pra Deus[...] Destroem milhares com trezentos loucos/Vencem cantando até ficarem roucos/A loucura de Deus é mais sábia que tudo/Não dá para explicar/Não tem como entender/É o esquadrão de elite do Deus poderoso/Escolhidos a dedo/Pra um plano audacioso/Desprezam o mundo e priorizam a fé[...] Podem ser loucos de tudo mas sua loucura funciona/Loucos por Deus/Um Deus que os impulsiona/Se este é o Deus a quem serves não procure entender/Faça loucuras por ele, sinta o seu poder/Loucos, que oram que oram e o céu se abre/Louco que clamam e o fogo desce [...] Faça loucuras pra agradar a Deus/ [...] Se entregue a morte porém não desista/Seja mais um louco pra agradar a Deus [...] (Grifo nosso).

Assim, tal texto parece desenhar um campo de batalha onde o personagem louco aparece como fanático membro de um restrito exército, um emissário da verdade a convocar outros soldados ao "enlouquecimento", garantindo-lhes recompensas em um plano transcendente. Já em "Sábia Loucura", o tom do discurso parece de polêmica entre dois sentidos:

Como conhecer, se nem mesmo se vê/Tantas palavras se afirmam, mas só os loucos crêem/Não te vejo, mas em tudo me olhas/Não te toco, mas sou sempre tocado por Ti/Em Deus, aprendi que até mesmo o sábio se cala/Em Sua Presença, não existem Palavras/Nem sempre Te entendo, mas nunca me falhas/A sabedoria de Deus é loucura pro homem/Sábio louco homem sem Deus/Louco sou por acreditar/No milagre de Cristo ao ressuscitar (Grifo nosso).

Dessa forma, duas loucuras parecem emergir. A primeira é a loucura à luz do conhecimento humano, que reúne o que a racionalidade é incapaz de explicar. Já o segundo uso do vocábulo "loucura" lhe dá um sentido de uma experiência cósmica que sugere uma resposta ao primado do conhecimento racional. É esse segundo sentido que apresenta o louco como aquele que vê o que ninguém vê e que enuncia um saber absoluto.

Sobre as condições históricas concernentes à aliança entre loucura e experiência mística, até o Renascimento era mais possível de ressoarem os ecos da significação cósmica da loucura, segundo a qual o louco teria um vínculo com o Sagrado e representaria a potência divina. Isso porque as forças que operavam naquele momento criaram espaços para que a loucura fascinasse como mistério e ensinasse como enigma.

Os enunciados das canções ligadas a esta zona de sentido ainda podem ser articulados a outras malhas discursivas, dado o ininterrupto proces- so de interanimação dialógica que caracteriza a enunciação. Estes sentidos que traçam um elo entre loucura e Sabedoria divina remontam também o século XVI. Naquele contexto, segundo os apontamentos foucaultianos, a verdade da loucura era ser interna à razão ${ }^{3}$, assim como podemos pensar a partir de alguns sentidos emergentes na análise das últimas canções acima. Assim sendo, Foucault apresenta o jogo entre razão, loucura e Sabedoria no momento em que a loucura passa a ser inscrita no próprio campo racional:

Em relação à Sabedoria, a razão do homem não passava de loucura; em relação à estreita sabedoria dos homens, a Razão de Deus é considerada no movimento essencial da loucura. Em grande escala, tudo não passa de Loucura; em pequena escala, o próprio Todo é Loucura. Isto é, a loucura só existe com relação à razão, mas toda a verdade desta consiste em fazer aparecer por um instante a loucura que ela recusa, a fim de perderse por sua vez numa loucura que a dissipa ${ }^{3}$.

\section{A Loucura como avesso da Razão: ilusão, insensatez e sofrimento}

Onze das trinta canções analisadas se relacionam a esta zona de sentido. Nesse território, a loucura e o louco figuram como "outros" da Razão e se ligam ao sofrimento, à ilusão e à insensatez.

A polissemia da loucura pode ser ilustrada por duas músicas cantadas por Alcione, mas que, a despeito de terem a mesma intérprete, dão sentidos distintos ao que seja loucura. Em uma delas, "Estranha Loucura", este signo anuncia uma postura insensata, exemplificada por comportamentos não convencionais junto à pessoa amada.

Minha estranha loucura/é tentar te entender e não ser entendida/É ficar com você Procurando fazer parte da tua vida/Minha estranha loucura/ É tentar desculpar o que não tem desculpa/É fazer dos teus erros/Num motivo qualquer a razão da minha culpa/Minha estranha loucura É correr pros teus braços quando acaba uma briga/Te dar sempre razão/E assumir o papel de culpado bandido/Ver você me humilhar/E eu num canto qualquer dependente total do teu jeito de ser/Minha estranha loucura/É tentar descobrir que o melhor é você/Eu acho que paguei o preço por te amar demais [...] (Grifo nosso).

Já na outra canção, "Faz uma Loucura por Mim”, o eu-lírico exige do parceiro transgressões às normas estabelecidas, o que confere à insensatez a condição para a continuidade do relacionamento.

Faz uma loucura por mim/Sai gritando por aí bebendo e chora/Toma um porre/picha um muro 
que me adora/Faz uma loucura por mim/Fica até de madrugada, perde a hora/Sai comigo pra gandaia noite afora/Só assim eu acredito nessa história/Que você sentiu/saudade de me ter/Põe na prática besteiras da memória/Pensa menos, faz de tudo, manda ver/Vem pra dentro, tenta ser da mesma escória/Como já fiz mil loucuras por você/Nós dois se é pra recomeçar que seja até o fim/Nós dois se não é pra ficar, não gaste o teu latim/Nós dois, só posso te aceitar ao ver que você faz/Uma loucura por mim [...]. (Grifo nosso)

Em comparação com a primeira canção da mesma intérprete, esses comportamentos desviantes continuam agregados ao signo da loucura, mas não são alçados como negativos ao relacionamento, e sim como requisitos para a sua manutenção, visto estarem agora associados à felicidade. Então, o fato de a mesma cantora interpretar canções com sentidos com similaridades e diferenças entre si em relação à loucura endossa nossa hipótese de que a polissemia e a polifonia se inscrevem nos discursos sobre a loucura no cotidiano, manifestando-se, inclusive, em produções de nossa cultura, como o são as canções, o que implica considerar que o autor do texto litermomusical não é a fonte do enunciado.

Para ilustrar a complexidade desta parte do território, em "O louco", de Os Químicos, o vocábulo "louco" se vincula a dois sentidos imbricados pela alusão à insensatez.

Dizem que o louco vai entrar/Falam que o louco vai sair/Não sabe o mundo como está/Se não jamais ia querer fugir/Estamos vivendo num mundo de loucos/Mas loucos normais não somos nós/ Nascemos e morremos por nosso veneno/Gemendo e gritando num globo a girar/Deixe sua cabeça ficar no ar/Pense e me responda se for capaz/De que vale o sono num berço de ouro/Se o travesseiro não o deixa dormir. (Grifo nosso)

O primeiro sentido ligado ao substantivo "louco" designa um personagem institucionalizado e excluído do convívio cotidiano, cuja insensatez se expressa pelo desejo de "retornar" a um mundo em crise. Já em outra parte do texto, o mesmo substantivo nomeia outros insensatos, aqueles que vivem em liberdade e são supostamente responsáveis pela degradação do mundo. Na canção, uma crítica sarcástica à sociedade atual pode ser vista. Além do que, neste exemplo, o signo da exclusão pelo enclausuramento acompanha o da loucura.

A arqueologia foucaultiana ressalta que a aproximação entre loucura e exclusão social, mediante a institucionalização do louco, deu-se em decorrência do paulatino silenciamento da "experiência trágica" da loucura. Tais sentidos se relacionam a uma "consciência crítica" do enlouquecimento. Foi a partir desse cenário e dessas configurações nas práticas discursivas que as vozes que cindem razão e desrazão e associam a loucura a esta última reverberaram com cada vez mais potência, a ponto de até hoje reverberarem significativamente e se espraiarem por diversos domínios de saber ${ }^{3}$.

\section{A Loucura como Patologia}

A cartografia permitiu observar também o enlace entre loucura e patologia, por conta de três canções em específico: "Louco por Ti”, "Já Virou Loucura" e "O Homem Louco".

Em "Louco por ti", novamente podemos vislumbrar embates entre sentidos diferentes relativos à loucura:

Não sei que se passa comigo/Pensei que eras só meu amigo/Não sei se sentes o mesmo/Que eu sinto dentro de mim/Não sei o que se passa comigo/Pensei que podia mentir/Mas quando eu te vejo, eu fico assim/Louco de desejo sem poder fingir/Eu estou louco (louca)/Fiquei louco (louca) /No segundo, em que te vi/Num olhar trocado, quase enfeitiçado /Sonhei acordado, ficar a teu lado/Sei que estou louco ...Louco por ti!/Não sei, que será o futuro/Se desta loucura me curo/ Mas sei, que há certas loucuras/Que fazem-me sentir tão bem [...] (Grifo nosso)

Esta canção parece admitir a existência de várias loucuras, umas que fazem bem e outras, mal. Ademais, em tal texto, há um intrigante duelo entre sentidos antagônicos que perpassam a avaliação do eu-lírico acerca do seu momento atual, os quais resultam de discursos e processos históricos distintos, um mais relacionado à "experiência trágica" da loucura e outro legatário da "consciência crítica" do desregramento. Em meio a isso, merece realce o trecho em que o eu-lírico realiza a associação entre loucura, doença e tratamento, conjeturando se a loucura que imagina possuir terá cura futuramente.

Já em "O Homem louco", vinculada ao grupo Roupa Nova, o louco emerge como um personagem excluído e caracterizado não só como perigoso, mas também como doente.

O homem louco aparece/E quebra o silêncio da sala/Por tempos viveu afastado/Desta cena onde a arma é a fala/Ele espera um dia saber/E um dia saber esperar/Mergulhado em prazer solitário/Sua imaginação ameaça/O saudável irmão tem medo/ Que seu grito arranque a mordaça/Ele espera um dia saber/E um dia saber esperar/Procurado, vendido, perdido/Ele aqui teve a sua lição/Na mentira dos outros reforça/A verdade da fé no irmão/ Que esperava um dia saber/Mas um dia não soube esperar. (Grifo nosso) 
Interessante notarmos que a exclusão versada em tal canção não se resume à retirada física do louco da cena cotidiana, já que são feitas referências a diversificados e sutis procedimentos de controle usados no trato da loucura, a fim de exorcizar os poderes e perigos do seu discurso. Parte do que é trazido na canção pode ser, inclusive, articulado a um primeiro grupo de procedimentos socialmente constituídos de controle do discurso. Tais procedimentos se caracterizam por serem externos ao discurso e incidirem sobre ele, tais como a interdição, a separação entre loucura e razão e a oposição entre verdadeiro e falso ${ }^{12}$.

As condições de produção do discurso que liga o louco à exclusão do convívio cotidiano começaram a se produzir no século XVII. Naquela época, aqueles que eram assim identificados passaram a ser internados junto a outros personagens desviantes, para fins de tão-somente separá-los da cena pública, pois a percepção da loucura na Idade Clássica era marcadamente moralizante, e não médica ${ }^{3}$.

Porém, as práticas discursivas que articulam loucura e doença mental são tributárias da apropriação daquela experiência pelo saber médico, na Modernidade. Naquela época, a institucionalização da loucura passou a se atrelar às propostas de arrefecer o temor da sociedade diante do enlouquecimento mediante tratamento especializado, a fim de restituir ao louco a razão ${ }^{3}$.

Ao argumentar como a loucura foi se tornando objeto de conhecimento na Modernidade, no fim do século XVIII e no começo do século XIX, os apontamentos foucaultianos se fazem importantes por desnaturalizarem a associação loucuradoença mental. Segundo tal pensador francês, o racionalismo médico e a dissolução semântica do conceito de desrazão foram importantes vetores, respectivamente, para a invenção da doença mental e para o estabelecimento de um discurso que incluísse a possibilidade de cura da loucura. Isso porque, até o surgimento da psiquiatria, o louco sequer era visto como alguém vitimado por doença, tampouco se entendia que a capacidade de exercício racional poderia ser restabelecida ${ }^{3}$.

\section{Discussão}

\section{Implicações para o campo da saúde mental}

Em algumas das trinta canções, sobretudo as agrupadas na primeira zona de sentido apresentada, a loucura e o louco servem como ferramenta de críticas a alguns processos que constituem a sociabilidade atual. Isto porque, por ve- zes, não são senão a sociedade e os ditos "normais" que figuram como "loucos" nos discursos literomusicais.

Sentidos como esses, então, acenam para um paradoxo da relação sociedade-loucura, tornando-se convenientes para problematizarmos as temáticas da "reabilitação psicossocial" e da "reinserção social" das pessoas com transtornos mentais, tão em voga no campo da saúde mental na atualidade. Assim sendo, de que modo "re-habilitar", "regenerar", "re-inserir" um tipo específico de indivíduo identificado como "louco", como se a sociedade que o identifica fosse reduto da virtude da sanidade, e não a responsável por sua fabricação? Como "re-habilitar" pela "reinserção" do "doente mental" no convívio cotidiano, se a própria sociedade também perdeu sua suposta sã condição?

Essas questões nos instigam a frisar a importância, para as discussões no campo da saúde mental, de, a partir dos signos da loucura e do louco, serem repensadas os limites e os alcances das formas de sociabilidade atuais no tocante à relação com a Diferença. Tal discussão, por sua vez, sugere que o debate sobre os encontros e desencontros contemporâneos entre loucura e sociedade seja tratado pela via ética, seguindo, para isso, a perspectiva foucaultiana, a qual trata da ética problematizando os modos de subjetivação.

Acerca disso, podemos pontuar que se faz importante à desconstrução de saberes e de práticas manicomiais que se leve a cabo reflexões sobre as possibilidades de relações alteritárias e sobre como a própria experiência de si pode ser problematizada atualmente. Portanto, de modo fecundo, pela ética imbricam-se desinstitucionalização da loucura e modos de subjetivação.

Assim, para Lavrador ${ }^{17}$, os preconceitos/rejeição em relação à loucura que pairam no imaginário social são um dos grandes impasses para a consolidação da Reforma Psiquiátrica brasileira. Consoante a esse posicionamento conceitual, Machado e Lavrador ${ }^{18}$ discutem o que chamam de "desejos de manicômio", que "[...] se expressam através de um desejo em nós de dominar, de subjugar, de classificar, de hierarquizar, de oprimir e de controlar. Esses manicômios se fazem presentes em toda e qualquer forma de expressão que se sustente numa racionalidade carcerária, explicativa e despótica".

Estariam alguns sentidos identificados nas canções a dialogar com discursos racionalistas sobre a loucura e com formas manicomiais de subjetivação? Sobre isso, pensamos que as figurações do louco em algumas canções, especialmente na quarta e quinta zonas de sentido, como 
aquele personagem desprovido de razão, institucionalizado e excluído do convívio social, são robustos indícios que possibilitam que tais questões sejam respondidas positivamente.

Estariam alguns sentidos circulantes nas canções a dar pistas de como nossa sociedade engendra modos de subjetivação a partir da articulação entre loucura e doença mental? Tais sentidos, com efeito, podem reforçar a idéia de que há possíveis manicômios invisíveis que atravessam as práticas sociais e os modos diários de funcionamento do pensar.

Destarte, seria coerente a idéia de que a própria sociedade, às vezes, legitima a institucionalização da loucura, por conta da gama de sentidos que coabitam o cotidiano? Pelo menos é o que fica plausível na análise das canções que ligam a loucura à patologia.

Porém, outras reverberações são possíveis. Algumas zonas de sentido - as duas primeiras, por exemplo - tanto podem potencializar a circulação da loucura como Diferença quanto têm o poder de evidenciar fissuras no paradigma racionalista. Tais zonas, então, oportunizariam vias para que a "desrazão" seja ouvida como um modo se funcionar possível e para que a loucura não necessariamente seja associada a formas institucionalizadas de viver ${ }^{19}$.

Já que admitimos que o discurso literomusical também integra o circuito discursivo que evoca os signos da loucura e do louco, seria possível articular algumas canções a dispositivos de normatização da Diferença? Ao mesmo tempo, outras possibilidades discursivas aparecem, sobretudo, nas canções relativas às duas primeiras zonas de sentido. Logo, algumas canções também poderiam se relacionar a estratégias de resistência ao controle da existência exercido quando o modo de subjetivação alicerçado no sujeito da razão é assumido como "normal"?

Para Foucault ${ }^{20}$, um dos desafios mais prementes na contemporaneidade talvez não seja o de "descobrir o que somos, mas recusar o que somos". No campo da saúde mental, essa afirmação nos inspira a assumirmos o ponto de vista de que a desinstitucionalização da loucura requer um desafio não restrito aos trabalhadores da saúde mental, senão que envolve uma gama mais ampla de agentes sociais: criar estratégias de resistência à fixação de identidades e à serialização dos processos de subjetivação, a partir, por exemplo, da problematização da lógica dicotômica normal-anormal.

\section{Considerações finais}

Pelo exposto, são patentes a polissemia e a polifonia dos signos "loucura" e "louco" no discurso literomusical, sugerindo distintos modos de conceber e conviver com a experiência do enlouquecimento em nosso cotidiano. Em virtude das cinco zonas de sentido identificadas, ressaltamos que a produção de sentidos sobre a loucura e sobre os seus personagens se caracteriza pelo embate de forças muitas vezes contraditórias, ratificando também a articulação foucaultiana entre discurso e relações microfísicas de poder.

Assim, a análise das canções nos permitiu supor disputas quanto aos usos dos signos "louco" e "loucura" no cotidiano. São justamente essas disputas e negociações em torno dos processos enunciativos que endossam a relevância de que o campo da saúde mental, principalmente no tocante à proposta de desinstitucionalização da loucura, abra-se ao caleidoscópio de paisagens psicossociais e múltiplos territórios semióticos delineados por conta dos diversos trânsitos dos sentidos sobre o louco e a loucura no dia-a-dia. Afinal, se são várias as loucuras circulantes, convém ao campo multidisciplinar da saúde mental escutar suas vozes e perscrutar suas condições de produção e suas eventuais ressonâncias.

Conforme bem lembra Foucault, o discurso "não é simplesmente aquilo que traduz as lutas ou os sistemas de dominação, mas aquilo por que, pelo que se luta"12. Por isso, pudemos reunir pistas de como o discurso literomusical se apresenta como arena dessa disputa de significação em torno da loucura no cotidiano.

A cartografia torna presumível que pontuemos que alguns sentidos se perfilam a modos instituídos de lidar com a loucura, fazendo funcionar, por exemplo, as cisões razão - desrazão, normal - anormal, bem como a associação loucura - doença, o estigma da periculosidade do louco e a exclusão deste personagem do dia-adia, mediante sua internação. Entretanto, outros sentidos circulantes podem ser vetores potentes de desinstitucionalização e de afirmação da legitimidade de diagramas subjetivos fugidios às normalizações cotidianas.

A partir do uso dos signos "louco" e "loucura”, alguns sentidos problematizam os próprios modos de sociabilidade, enquanto outros encorpam o coro das vozes da desrazão, insinuando positividades na experiência da loucura. Outros sentidos também veiculados em algumas canções podem se aproximar da perspectiva da desinstitucionalização da loucura, por questionarem, de algum modo, a distância abismal entre 
razão/desrazão e entre normalidade/anormalidade. O trânsito de tais sentidos no cotidiano das relações sociais, porquanto, pode ser útil para a relativização da idéia do louco como perigoso e para que sejam experimentadas novas relações com a Diferença.

Apesar desta multiplicidade, um ponto de convergência entre as várias zonas de sentido pôde ser observado: na cartografia, os signos da "loucura" e o "louco" caracterizam-se por inspirarem descontinuidades, aparecendo nas canções junto a experiências disruptivas.

Por fim, vários sentidos identificados transitam, simultaneamente, por diversos domínios de saber, como a religião, a ciência e a filosofia, confirmando a inscrição do discurso literomusical no âmbito interdiscursivo9. Percebemos isso no

\section{Referências}

1. Amorim AKMA, Dimenstein M. Desinstitucionalização em saúde mental e práticas de cuidado no contexto do serviço residencial terapêutico. Cien Saude Colet 2009; 14(1);195-204.

2. Alverga AR, Dimenstein M. A Reforma Psiquiátrica e os Desafios da Desinstitucionalização da Loucura. Interface Comun Saúde Educ 2006; 10(20);299-316.

3. Foucault M. História da loucura na idade clássica. $8^{\mathrm{a}}$ ed. São Paulo: Perspectiva; 2005.

4. Spink MJ, organizadora. Práticas discursivas e produção de sentidos no cotidiano: aproximações teóricas e metodológicas. 3a ed. São Paulo: Cortez; 2004.

5. Bakhtin M. Marxismo e filosofia da linguagem. São Paulo: Hucitec; 2002.

6. Cunha MCP. Cidadelas da Ordem: a doença mental na República. São Paulo: Brasiliense; 1990.

7. Foucault M. A arqueologia do saber. Petrópolis: Vozes; 2000.

8. Spink MJ; Frezza RM. Práticas Discursivas e produção de sentidos: a perspectiva da Psicologia Social. In: Spink MJ, organizador. Práticas discursivas e produção de sentidos no cotidiano: aproximações teóricas e metodológicas. 3a ed. São Paulo: Cortez; 2004. p. 17- 40.

9. Costa NB. Fumo, lei, ciência e carnaval: a circulação do discurso antitabagista na internet. In: Costa MFV, Barros RR, organizadoras. Diversidade cultural e desigualdade: dinâmicas identitárias em jogo. Fortaleza: UFC; 2004. p. 177-202.

10. Costa NB. A produção do discurso literomusical brasileiro [tese]. São Paulo: Pontificia Universidade Católica de São Paulo (PUC SP); 2001.

11. Rolnik S. Cartografia sentimental: transformações contemporâneas do desejo. São Paulo: Estação Liberdade; 1989.

12. Méllo RP, Silva AA, Lima MLC, Paolo AF. Construcionismo, práticas discursivas e possibilidades de pesquisa em psicologia social. Rev Psic e Soc 2007; 19(3):26-32. fato de que o enlace entre loucura e erro não é exclusivo do saber psiquiátrico, bem como no fato de que a conotação moral acerca da razão e da desrazão não se localiza unicamente, por exemplo, em discursos jurídicos, médicos, científicos ou filosóficos, presentificando-se, inclusive, em canções veiculadas contemporaneamente.

\section{Colaboradores}

JPP Barros e MSB Jorge participaram igualmente de todas as etapas de elaboração do artigo.

13. Foucault M. A ordem do discurso. São Paulo: Loyola; 2004.

14. Letras.mus.br [acessado 2009 jul 27]. Disponível em: www.letras.terra.com.br

15. Kastrup V. O funcionamento da atenção no trabalho do cartógrafo. Rev Psic e Soc 2007; 19(1);15-22.

16. Spink MJ, Medrado B. Produção de sentido no cotidiano: uma abordagem teórico-metodológica para análise das práticas discursivas. In: Spink MJ, organizador. Práticas discursivas e produção de sentidos no cotidiano: aproximações teóricas e metodológicas. 3a ed. São Paulo: Cortez; 2004. p. 41-61.

17. Lavrador MCC. A Psicologia e os Desafios Contemporâneos da Reforma Psiquiátrica. In: Jacó-Vilela AM, Sato L, organizadoras. Diálogos em Psicologia Social. Porto Alegre: Evangraf; 2007. p. 361-370.

18. Machado LD, Lavrador MCC. Loucura e subjetividade. In: Machado LD, Lavrador MCC, Barros MEB, organizadores. Texturas da psicologia: subjetividade e política no contemporâneo. São Paulo: Casa do Psicólogo; 2001. p.45-58.

19. Baptista LA. A cidade dos sábios. São Paulo: Summus; 1999.

20. Foucault M. O sujeito e o poder. In: Rajchman J, organizador. Foucault: a liberdade da filosofia. Rio de Janeiro: Jorge Zahar; 1995.

Artigo apresentado em 27/07/2009

Aprovado em 02/02/2010

Versão final apresentada em 01/03/2010 